\title{
'Discourse on the Go': Thematic Analysis of Vehicle Graffiti on the Roads of Egypt
}

\author{
Mohamed El-Nashar \\ Language and Translation Department, College of Language and Communication, Arab Academy for Science, \\ Technology and Maritime Transport, Egypt \\ E-mail: Melnashar68@gmail.com \\ Heba Nayef (Corresponding author) \\ Humanities Department, College of Language and Communication, Arab Academy for Science, Technology and Maritime Transport, Egypt \\ E-mail: hnayef@gmail.com
}

Doi:10.7575/aiac.alls.v.7n.5p.227

URL: http://dx.doi.org/10.7575/aiac.alls.v.7n.5p.227
Received: 02/07/2016

Accepted: 19/08/2016

\begin{abstract}
This paper investigates graffiti drawn on vehicles in Egypt as an expression of their authors' social values, religious ideologies and political affiliations. Little research has been done in Egypt on these meaning-loaded messages. This paper gives further evidence that graffiti are a very powerful mode of expression for groups that feel disenfranchised by the wider society. The data comprise (614) written graffiti taken from both highway and in-city vehicles from different parts of Egypt. This paper employs Fairclough's (1995) post-structuralist model of discourse analysis which extends the concept of discourse from the traditional and natural 'language in use' to be a social practice per se. One of the aims of this study is to explore the various discourse domains of vehicle graffiti in Egypt through thematically analyzing their patterns of usage. For this aim, the authors have devised a four-pronged thematic classification of such graffiti. The paper also tackles some of the lexical features of graffiti and addresses the language and language variations used. Results show that religious expressions constitute more than half the data. It is also shown that graffiti about the self or car are positive whereas statements about 'the other' are negative. The analysis reveals a strong positive inclination in the social and philosophical expressions with almost nonexistent political graffiti.
\end{abstract}

Keywords: Graffiti, post-structuralist model, Discourse Analysis, discourse domains, Egypt

\section{Introduction}

In the ancient city of Hierakonpolis, modern Aswan, in Upper Egypt, Egyptologists found one of the oldest graffiti tableaus on which the king has inscribed his name 'Scorpion' and the story of his victory over the king of Naqada, modern Qena, also in Upper Egypt, which led to the unification of the south under one ruler (Hendrickx Darnell \& Gatto, 2012). Following in their ancestors' footsteps 5,250 years later, drivers of vehicles rolling the streets of Egypt write on their cars messages that vary in nature but, like those of their pre-dynastic ancestors, are expressions of their social, religious and political identities and beliefs.

The purview of this paper will be confined to messages printed on stickers, written or drawn on the vehicle, not for a commercial purpose but as an expression of the individual's social values, religious ideologies and political affiliations. Such statements are in themselves a very powerful mode of expression for groups that essentially feel disenfranchized and marginalized by the wider society (Farnia, 2014). Through running a qualitative and quantitative analysis of (614) of these vehicle graffiti, this study attempts to discern the thematic categories of vehicle graffiti in Egypt and study the lexical features of this type of 'mobile discourse' (Bloch, 2000:48).

\subsection{Literature Review}

The term 'graffiti' is derived from the Italian word 'graffito'. It is used to refer to "any form of writing or images on the walls or surfaces of public buildings, parks, toilets, buses or trains, usually bearing some political or sexual contents, a lover's pledge, proposition, or obscene words" (Chiluwa, 2008:274).

Language is an institution that does not belong equally to everyone (Cameron, 1985) and is rather dominated by a symbolic elite (van Dijk, 2006) who control public discourse and from whom we learn our prejudices and beliefs. Such 'symbolic elite', represented in journalists, media persons and politicians, set for us what is important and what is to be disregarded, what to be accepted and what is to be rejected. Through their text and talk they produce and reproduce ideologies and beliefs (van Dijk, 2001). Graffiti, as scholars tend to regard them, are the means to strike, or rather redress, the balance of such discourse, thus constituting a challenge to this form of domination and injustice. It is viewed as an egalitarian means of expressions, giving voice to the marginalized, helping them to speak the unspeakable (Best, 2003; Bloch, 2000; Gadsby, 1995; Moonwomon, 1995; Obeng, 2000b). Some scholars claim that graffiti, 
especially those that are available to a large audience as it is the case with vehicle graffiti, are not just the marginalized individuals' expression of themselves but they also serve as a stimulus for the public to engage in a public discussion of issues (Nwoye, 1993).

Yet, there is another point of view that sees graffiti as dominant rhetoric which does not allow other people to give responses to them. As such, graffiti are not viewed as egalitarian, for they do not offer chances for prospective audience to engage in a dialogic discourse with the graffiti owners who do not care how their graffiti sound and how they are received (Basthomi, 2009). This controversy of whether graffiti are egalitarian or authoritarian in nature does not deny the fact that graffiti in general, and vehicle graffiti in particular, serve as a platform for social communication in various societies (Caribbean, Best, 2003; Egypt, Gröndahl, 2012, Lennon, 2014; Ghana, Obeng, 2000a, 2000b; Greece, Kalerante \& Mormori, 2005; Indonesia, Basthomi, 2009; Iran, Farnia \& Tohidian, 2013; Farnia, 2014 , Sheivandi et al. 2015, Mirzaalikhani, 2011; Israel, Bloch, 2000, Hanauer 2004, Salamon, 2005; Kenya, Yieke 2003; Mexico, Grider 1975; Nigeria , Nwoye, 1993, Chiluwa, 2008; Poland, Jankowska 1999, Szpila, 2003, 2012; Spain; Bunting, 2012; Sri Lanka, Peiris \& Jayantha 2015; United States, Case, 1992, Hunt, 1996)

Over the past forty years, the universality of graffiti has attracted the attention of scholars from various disciplines. Gadsby (1995) recognized nine main approaches to studying graffiti: Cultural, gendered, folkloric, quantitative, aesthetic, motivational, preventative, popularization and linguistics. (For more details, see Gadsby, 1995). Scholars adopting the linguistic approach have different aims while conducting their research work. They view graffiti as a linguistic phenomenon that involves both form and content and makes use of discourse to mean something other than itself (Gross et al. 1997; Mwangi 2012). One of the earliest studies of graffiti from a linguistic approach was done by Grider (1975) in which she investigated the cultural and linguistic functions of con safos graffiti within the MexicanAmerican community. Some other scholars studied graffiti as political discourse (Obeng, 2000a, 2000b; Bloch, 2000; Case, 1992; Salamon, 2005), while others viewed them as a gendered discourse (Moonwomon, 1995; House, 2007) as a means of language learning (Mwangi, 2012) or as discourse of religious identity (Chiluwa, 2008). In addition, Adams and Winter (1997) studied graffiti as a discourse genre that sets the identity of gang members and mark the boundaries of the gang as a social community.

Some scholars tend to acknowledge two types of graffiti: Public and private (Basthomi, 2009; Emmison \& Smith 2000), while others, like Gadsby (1995), recognized six different types: Latrinalia, public, tags, historical, folk epigraphy, and humorous (For a more detailed discussion, see Gadsby, 1995). Public graffiti are those writings that are done in open areas where there is greater possibility for the writer to be seen and known (Reisner, 1971). The more public the graffiti are, the more adherent to the norms of public discourse they are, with fewer obscenity and pornography. To this public type belong vehicle graffiti.

Scholars studying graffiti or stickers on various vehicles used a variety of terms to refer to this phenomenon: Bumper stickers (Bloch, 2000; Case, 1992 Salamon, 2005, House, 2007 ) vehicle stickers (Chiluwa, 2008), truck graffiti (Basthomi, 2009; Farnia \& Tohidian, 2013) or car written manuscripts (Divsalar \& Nemati, 2012). It is worth noting that the term 'bumper stickers' was used by Rains et al. (2009) to refer to sayings that are included in an e-mail signature file following personal identifiers such as one's name, phone number, and postal address. For the purposes of this study, we opt for the term 'vehicle graffiti'.

\subsection{Objective of the Study}

Through running a qualitative and quantitative analysis of the data, this paper addresses three analytical points. The first point is to determine the various discourse domains of vehicle graffiti in Egypt through analysing the content and patterns of usage of messages on vehicle graffiti. The second point tackles some of the lexical features displayed in the data under investigation. The third point addresses the form, which means here the language and language variation used in vehicle graffiti in Egypt in various discourse domains The study investigates these points by providing a thematic analysis of the data using the post-structuralist model of discourse analysis framework which will be discussed in the following section.

\subsection{Theoretical Framework}

The data are analyzed within the framework of the post-structuralist model of discourse analysis (Fairclough 1995). Fairclough $(1989,1995)$ extends the concept of discourse from the traditional, spontaneous and natural 'language in use' (Brown and Yule, 1983) and a tool to understand the intentions of the speaker (van Dijk, 1985) to be in itself a social practice (Chiluwa, 2008). Discourse is looked upon as an agent in the hands of political and social groups aiming at influencing and dominating other political and social groups. It is both part and product of social practices. Adopting this model, this paper studies vehicle graffiti in Egypt as a social practice, that is, the product of discursive and other practices in the Egyptian society on both the individual and institutional levels. Viewed as discursive tools in the hands of their authors, such texts are in fact the product of a complex system of social and institutional practices which produce and reproduce them with a view to maintaining their continuous existence (Fairclough, 1995). These graffiti texts, which serve as a discursive social practice, provide a clear image and profound understanding of the various political and social changes in the society. 


\section{Methodology}

\subsection{Data Collection and Sampling}

The data were collected from different locations inside Egypt from July, 2015 till January, 2016. The first set of the data was collected from highway locations; namely, Cairo-Alexandria highway, Cairo-Fayoum highway and Cairo-Sinai highway. Highway vehicles under investigation fall into three main categories: Huge, medium-sized and small trucks. They are all privately owned. The second set incorporates in-city locations which are: a) In the capital Cairo, ElHelmeya microbus terminal (east Cairo), El-Asher microbus terminal (east Cairo), Makram Ebeed microbus terminal (east Cairo), Moneeb microbus terminal (south Cairo) and Ahmad Essmat microbus terminal (east Cairo); b) Alexandria, Raml Microbus terminal; c) In the village of Shakshouk, Fayoum governorate, south of Cairo; d) Rad Sudr city, South Sinai. Vehicles under investigation in this set of locations all served as privately-owned means of public transportations and fall into three categories: Taxi cabs, microbuses and Tuk-tuks (or, rickshaws), (very small threewheeled cars that are used instead of taxis in the narrow streets of Egypt's poor areas or inside villages).

For each vehicle one picture or more was taken from all sides. These pictures were then examined and the graffiti thereon recorded. Messages were gathered from bumper stickers, car rears, window decals, as well as personalized license plates. Commercials were then excluded. Written texts were then classified into a set of categories that will be discussed in section 2.2 below.

In Egypt, vehicle graffiti take two main forms: Pictorial and written. For the purpose of this study, we shall focus on the written graffiti. It is worth noting, however, that written graffiti far outnumber pictorial graffiti, as will be discussed in section 3. below.

All Arabic graffiti have been translated by the first author, except for the Quranic citations, which are taken from Ali's (1975) translation of the Glorious Quran. Such Quranic citations will all be put between double inverted commas.

\subsection{Categories and Classification}

This section discusses the thematic classification of the graffiti with reference to some lexical features as well as the language (either Arabic or English) and language variations detected in the data under examination.

\subsubsection{Thematic Classification and Discourse Domains}

We have proposed four discourse domains to be used to classify vehicle graffiti in Egypt: Religious expressions; identity expressions; social and philosophical expressions and finally political expressions. We then sub-classified these domains so as to discern the way vehicle graffiti in Egypt function as a dynamic means of social communication in the Egyptian society. Following is a brief exposition of the proposed categories and subcategories in this first level of analysis:

Table 1. Thematic classification of graffiti in Egypt

\begin{tabular}{|c|c|c|}
\hline & Category & Sub-category \\
\hline \multirow{4}{*}{ I } & Religious Expressions & Reaffirmation of faith \\
\hline & & Protection against envy \\
\hline & & Preaching \\
\hline & & Invocations \\
\hline \multirow[t]{2}{*}{ II } & Identity expressions & Self- and Car identity \\
\hline & & Identity of 'the other' \\
\hline \multirow[t]{6}{*}{ III } & Social \& Philosophical Expressions & Contentment \\
\hline & & Motivational expressions \\
\hline & & Love \\
\hline & & Wisdom \\
\hline & & Complaints \\
\hline & & Threats \\
\hline \multirow[t]{2}{*}{ IV } & Political Expressions & Patriotism \\
\hline & & Political criticism \\
\hline
\end{tabular}

In terms of discourse domains, although categories are sometimes bound to overlap, some features are given to distinguish one sub-category from the other. In 'religious expressions', for instance, while 'reaffirmation of faith' is dedicated to messages in which the author re-asserts his belief in God, 'preaching' involves messages from the author to the audience, the onlookers, exhorting them to abide by God's teachings. 'Invocations', on the other hand, are messages from the author to God asking for support, help, patience, etc. 


\subsubsection{Language and Language Variation}

If identifying the discourse domain of vehicle graffiti in Egypt is the first level of analysis, we propose a second level which deals more with the form than with the content; that is, the language used as well as the language variation, or language map. As a diaglossic language, Arabic has three variations used freely by its speakers. In Egypt, the three levels of Arabic used are: Classical Arabic, which is the language used in the Quran and classical Arabic literature; Modern Standard Arabic or FuSHa, which is the language used in written texts (i.e. the press and formal settings) and finally vernacular Arabic or colloquial Arabic, which is the language used for everyday conversations (For further details, see Younes, 2006; Ferguson, 1959). Standard English is also used, though on a much smaller scale, and thus we included it in our taxonomy as shown below.

\section{Results and Discussion}

The data yielded a total of (614) written graffiti; 284 from highway vehicles and 330 from in-city vehicles. Also detected were only (11) pictorial graffiti, which lie beyond the purview of this study. As mentioned earlier, the study has three points of analysis: the identification of thematic classification and discourse domains, some salient lexical features that are displayed in the study, and the identification of the language and language variation used. In the following sections, the results of each analytical point are discussed.

\subsection{Thematic Classification and Discourse domains}

\subsubsection{Religious Expressions}

Religious expressions accounted for 328 (53.42\%) graffiti, more than half the number of all graffiti messages detected in the data under investigation. The remaining graffiti occurrences $(286,46.57 \%)$ belong to the three other discourse domains.

\subsubsection{Islam and Christianity}

Egypt is largely a Muslim community with roughly (90\%) of the population Muslims and $10 \%$ Christians (See the World Fact Book, Central Intelligence Agency at: https://www.cia.gov/library/publications/the-worldfactbook/geos /eg.html). Human Rights Watch (HRW) issued reports (Among which was a report released on August 21, 2013 headlined "Egypt: Mass attacks on churches") that Coptic Christians were the subject of vandalism, destruction and murder especially after June $30^{\text {th }}$ revolution, as Muslim Brotherhood supporters blamed Christians for being behind the ouster of their Islamist president Mohamed Morsi. This explains the barely extant occurrence of Christian expressions in the data, only (11) graffiti (3.35\%) against 317 cases (96.64\%) for Islamic expressions (See Figure 1 below). It is worth noting that those (11) occurrences of Christian expressions were all spotted outside Cairo, (7) in Alexandria and (4) in Cairo-Sinai highway.

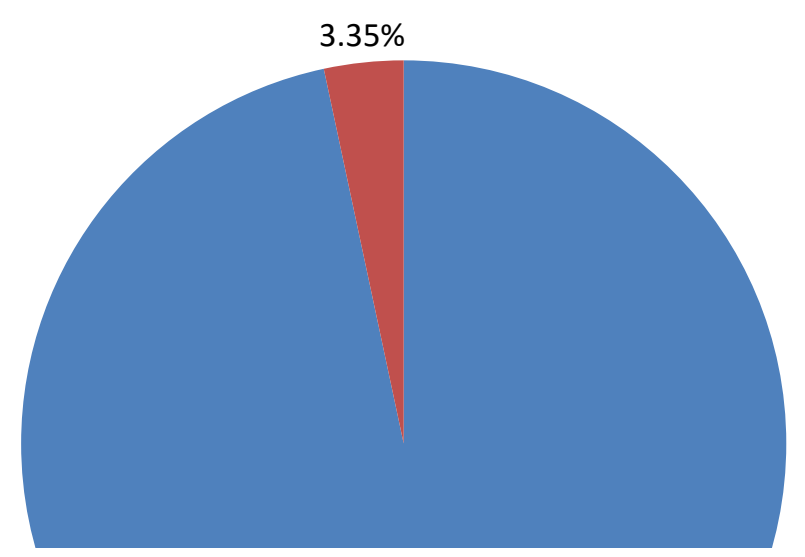

Figure 1. Islamic \& Christian vehicle graffiti

\subsubsection{Types of Religious Graffiti}

\subsection{Reaffirmation of Faith}

The majority of the religious expressions in the data under investigation fall under the category of 'reaffirmation of faith', accounting for 176 occurrences (53.66\%). The authors used a variety of discursive tools to reaffirm their faith. Three main tools were recognized: Quranic citations, religious sayings and personal declarations. While Quranic citations are confined to direct quotations from the Quran, religious sayings are not cited from the Quran and are subcategorized into: Common religious sayings, God's Names (99 Names according to Islamic tradition), and Names of Prophet Muhammad, Jesus and Christian saints. Personal declarations, on the other hand, are the graffiti author's thoughts reflected in a dialogic discourse with God or the Prophet.

Authors used Quranic citations in the majority of cases as a tool to reaffirm faith. They either cited a whole Quranic verse or part of it. There were no recorded biblical citations in the data. Authors also employed other religious sayings (i.e. non-Quranic, non-biblical): Quoting common religious Islamic/Christian sayings; writing God's Names, writing 
names such as those of Prophet Muhammad, Jesus and Christian saints. There were also numerous citations of Islamic shahadah (i.e. testimony where a Muslim bears witness that there is no god but Allah and that Muhammad is His Messenger).

Table 2. Discursive tools of Reaffirmation of Faith

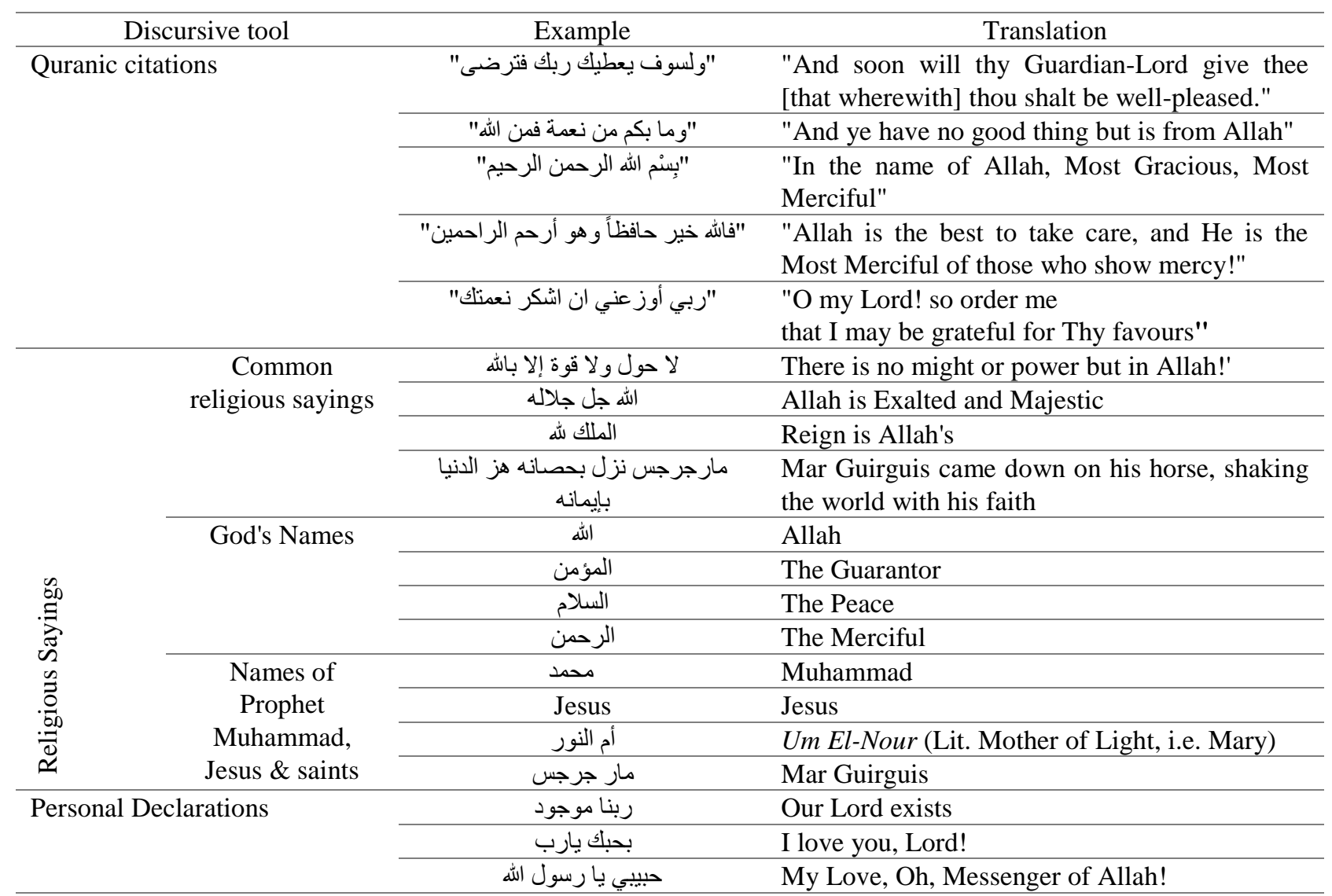

\subsection{Protection against envy}

One of the dominant characteristics of Egyptian society past and present is the inherent fear of the supernatural power of envy. Egyptians believe that only a higher power can ward off the evil eye. Language is a mirror that reflects and sediments dominant beliefs in a society. It is the product of the ideology of the society and it reproduces these ideologies. Thus, we find in the data under investigation that vehicle graffiti not only mirror societal beliefs and ideologies but also propagate them. We have found that almost a third of vehicle graffiti texts that fall into the religious domain address this 'anti-envy' belief (92 graffiti, 29.27\%). As in the previous subcategory, authors express this through employing two of the discourse tools mentioned earlier; namely, Quranic citations and citation of common religious sayings. The data reveal a heavy use of Quranic verses that tackle envy as against citations of common religious sayings. Below is a table that illustrates the occurrences of Quranic citations as against common religious sayings.

Table 3. Discursive Tools of Protection against Envy

\begin{tabular}{|c|c|c|}
\hline Discursive Tool & Example & Translation \\
\hline \multirow[t]{4}{*}{ Quranic citations } & "فاله خير حافظاو هو أرحم احمين" & $\begin{array}{l}\text { "Allah is the best to take care, and He is the Most Merciful of } \\
\text { those who show mercy!" }\end{array}$ \\
\hline & " أوزيناها للناظرين وحفظناها & $\begin{array}{l}\text { "and made them } \\
\text { fair-seeming to [all] beholders. And [moreover] We have } \\
\text { guarded them from every cursed devil." }\end{array}$ \\
\hline & 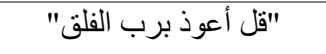 & "Say: I seek refuge with the Lord of the Dawn" \\
\hline & "ومن شر حاسد إذا ومن & $\begin{array}{l}\text { "And from the mischief of the envious one as he practises } \\
\text { envy." }\end{array}$ \\
\hline \multirow{3}{*}{$\begin{array}{l}\text { Common religious } \\
\text { sayings }\end{array}$} & بسم الله ما شاء الله & In the name of Allah, 'Allah's will [be done]! \\
\hline & الحارس هو الله & The Guardian is Allah \\
\hline & العين صابتني ورب العرش نجاني & The evil eye hit me, and the Lord of the Throne saved me. \\
\hline
\end{tabular}




\subsection{Preaching}

The data yielded (32) occurrences that fall within the preaching category (9.76\%). It is inherent in the teachings of the Quran that preaching and sound behavioral guidance is not only the duty of religious institutions but of every Muslim as well. Such preaching is enjoined in the Glorious Quran: كُنتم خير أمه اخرجت للناس تأمرون بالمعروف وتنهون عن المنكر وتؤمنون "بالهاب("Ye are the best of peoples, evolved for mankind, enjoining what is right, forbidding what is wrong, and believing in Allah," (Sura Al-Imran 3:110).

Vehicle graffiti reflect these beliefs in assuming the role of a preacher. Trucks, small or big, taxis, small buses roll in the streets of Egypt carrying on their vehicles messages urging everyone who reads them to follow the accepted code of conduct. Table (4) below shows the most salient exhortations in this discourse domain.

Table 4. Most Salient Preaching Exhortations

\begin{tabular}{|c|c|c|}
\hline Example & Translation & Type of exhortation \\
\hline يا عم يللى إنت مش مالك دع المالك & $\begin{array}{l}\text { You are not the Master, so let the reign to the } \\
\text { Master (i.e. Allah) }\end{array}$ & Do not be intrusive \\
\hline 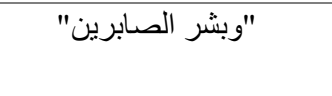 & $\begin{array}{l}\text { "Give glad tidings to those who patiently } \\
\text { persevere"(Al-Baqara, or The Heifer, } 2: 155)\end{array}$ & Be patient \\
\hline الفاتحه للنبى & $\begin{array}{l}\text { (Read) Al-Fatihah (or, the Opening Chapter of } \\
\text { the Quran) in praise of the Prophet }\end{array}$ & Be righteous, Remember God \\
\hline 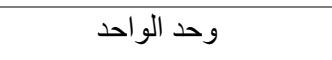 & Proclaim that (Allah) is the One & Remember God, \\
\hline 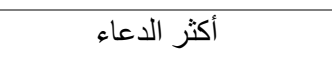 & Say many invocations (to Allah) & Be righteous, pious \\
\hline مهما تكبر الله أكبر & However great you become, Allah is greater. & $\begin{array}{l}\text { Be modest, do not be arrogant or } \\
\text { oppressive }\end{array}$ \\
\hline إذكر الله & Remember Allah & $\begin{array}{c}\text { Be righteous, observe religious } \\
\text { teachings }\end{array}$ \\
\hline
\end{tabular}

\subsection{Invocations}

The least common category of religious expressions in the data was found to be 'Invocations' graffiti. The analysis reveals only 24 instances $(7.31 \%)$. For a graffito to be classified as falling under this category, it has to include a personal appeal, request or prayer to God. Invocations are exemplified in the following table.

Table 5. Most Salient Invocations Graffiti

\begin{tabular}{|c|c|}
\hline Example & Translation \\
\hline احفظها يا رب & Lord, keep it! (i.e. the vehicle) \\
\hline معانا يارب & Lord, be with us! \\
\hline استر ها يارب & Lord, save us! \\
\hline محتاجلك يارب & Lord, I need you! \\
\hline 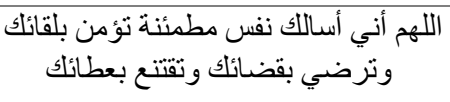 & $\begin{array}{l}\text { Lord, I ask you to bestow upon me a righteous soul that believes in meeting } \\
\text { you, is satisfied with your fate and content with your offering. }\end{array}$ \\
\hline يابركة أم النور & $\begin{array}{l}\text { May the blessing of umm El-Nour (Lit. Mother of Light, or Mary) be } \\
\text { bestowed upon us. }\end{array}$ \\
\hline
\end{tabular}

Figure 2 below shows the percentage taken by each type of the religious graffiti: 


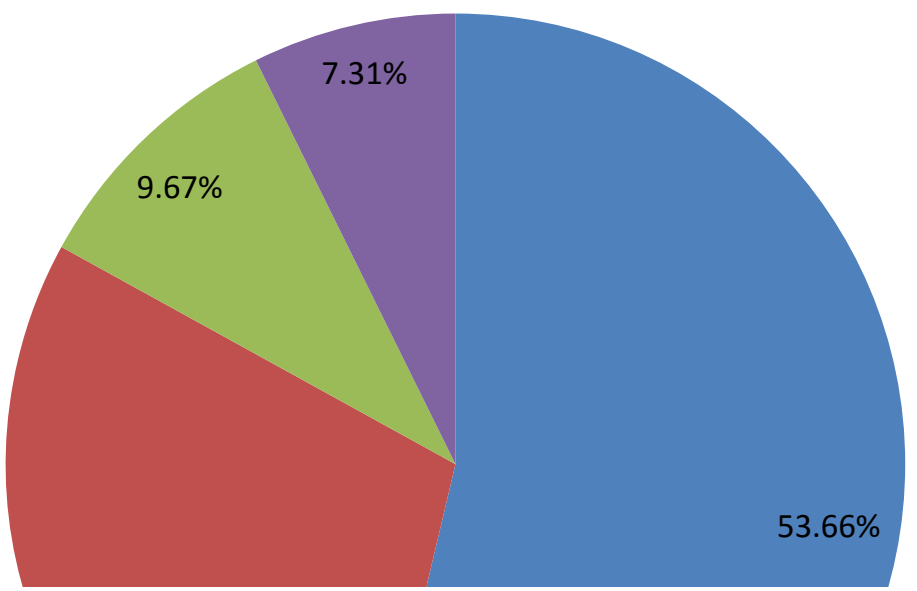

Figure 2. Types of Religious Graffiti

\subsubsection{Forms of Religious Graffiti (Quranic \& Non-Quranic)}

It has been found that out of (328) graffiti representing all categories of religious discourse domain, Quranic citations accounted for (121) occurrences as against (207) instances of other religious graffiti expressions (See Figure 3 below):

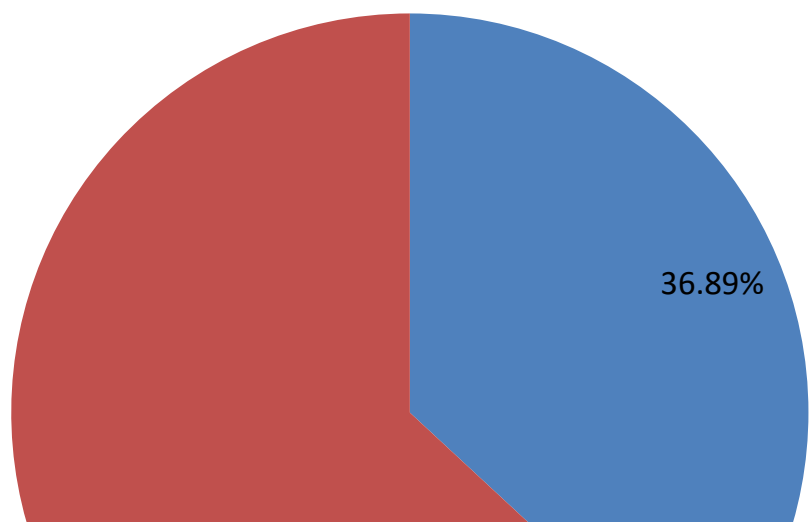

Figure 3. Quranic Citations \& Other Religious Graffiti

\subsubsection{Identity Expressions}

The discourse domain that constitutes the second largest number of occurrences in the data is the identity expression graffiti, scoring 193 occurrences (31.43\% of the data under investigation). Identity expression texts are those graffiti phrases that deal with self-/car identity or focus on the identity of 'the other'. The former includes names, nicknames, family and statements about self or driving habits. The latter includes any text that contains a reference to, or description of, 'the other' as illustrated by Table (5) below. The analysis reveals that vehicle graffiti authors are obviously more engaged in talking about themselves, their families or their cars, i.e. the first category, (147 instances, $76.16 \% \%$ ) than about 'the other', the second category, (46 instances, 23.83\%).

It has also been found that the frequency of using phrases and words with positive connotations is much higher in the self- identity graffiti than it is in those dealing with 'the other'. Thus, in self-identity graffiti, authors used a significant number of names, nicknames and family names (104 occurrences, $70.75 \%$ ) in a discursive move that implies pride in self and esteem of family ties. This pride is further proven by statements about self or car, involving phrases and words that carry positive connotations (See Table 5 below): 
Table 5. Types of Self-/Car Identify Graffiti

\begin{tabular}{|c|c|c|}
\hline Type & Example & Translation \\
\hline \multirow{8}{*}{$\begin{array}{c}\text { Names/ } \\
\text { Nicknames/ } \\
\text { Family }\end{array}$} & أبو أحمد & Abu Ahmed (Lit. Ahmed's father) \\
\hline & الأميره نورا & Princess Nura \\
\hline & رودي & Rudy \\
\hline & حُمُص أخو آيه وبسمله & Hommos, brother of Aya and Basmala \\
\hline & الكينج & The King \\
\hline & 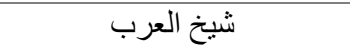 & (Lit. The Sheikh of Arabs) \\
\hline & ملك الجبل & King of the mountain \\
\hline & ملك الأسفلت & (Lit. King of the asphalt), i.e. a very skillful driver \\
\hline \multirow{4}{*}{$\begin{array}{l}\text { Statements } \\
\text { about self }\end{array}$} & هو ده الدبور & (Lit.This is the wasp), i.e. this is fearsome man \\
\hline & يا جبل ما يهزك ريح & $\begin{array}{l}\text { (Addressing himself) Mountain, the wind cannot shake you (i.e. I } \\
\text { can endure pain, hardships stoically; steadfast) }\end{array}$ \\
\hline & التقدير خسرنا كتير & (Our) appreciation of others made us lose a lot \\
\hline & King of the road & King of the road \\
\hline \multirow{5}{*}{$\begin{array}{l}\text { Statements } \\
\text { about car }\end{array}$} & الحلوه نعناعه وكايده الجماعه & Sweetie car, makes others turn green \\
\hline & 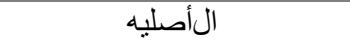 & Original (Car) \\
\hline & عسليه و العين عليا & So cutie it leaves people staring \\
\hline & الأسفلت مولع ليه النصر ماشي & $\begin{array}{l}\text { Why is the asphalt on fire? Coz al-Nasr (i.e. a local car) is rolling } \\
\text { on it. }\end{array}$ \\
\hline & الدلوعة الدة & (Lit. the pampered girl) \\
\hline
\end{tabular}

The analysis also showed that all of the (46) instances referred to 'the other' in a negative tone, whether 'the other' is a friend, the other sex (women) or the community, as shown Table (6) below:

Table 6. Types of 'the Other' in Graffiti

\begin{tabular}{|c|c|c|}
\hline Type & Example & Translation \\
\hline \multirow[t]{7}{*}{ Friend } & اللي يصاحب ر اجل يا بخته & $\begin{array}{l}\text { How lucky he is who befriends a man (i.e. an honest, } \\
\text { reliable person)! }\end{array}$ \\
\hline & لو صاحبك خانك اعتبره دخانك & $\begin{array}{l}\text { If you're betrayed by your friend, consider him your } \\
\text { smoke (i.e. worthless) }\end{array}$ \\
\hline & الناقص بناقص منه & You won't need a villain \\
\hline & مفيش صاحب يتصاحب & There's no one to befriend \\
\hline & ميستهلوش - معلمين بالأونطه & They don't deserve. Only fake masters! \\
\hline & يا عّم ياللي جي تدينا نصائح دانت كلك فضايح & Mr. Disgrace, don't give us advice \\
\hline & العيب مش في الحديده العيب في السو اقين & The new driver, not the car, is to blame \\
\hline \multirow{2}{*}{$\begin{array}{l}\text { The other sex } \\
\text { (women) }\end{array}$} & وارء كل مديون إمر اة & Behind every indebted man there is a woman \\
\hline & الثيطان أستاذ الرجل وتلميذ المر اه & $\begin{array}{l}\text { The devil is the master of man and disciple of the } \\
\text { woman }\end{array}$ \\
\hline \multirow[t]{3}{*}{ The community } & كنت عصفور أكلوني عملت أسد صاحبوني & $\begin{array}{l}\text { (Lit. I acted like a sparrow, they ate me; I acted like } \\
\text { a lion, they befriended me) Or: } \\
\text { When I was timid, I was overpowered; when I } \\
\text { became bold, they befriended me. }\end{array}$ \\
\hline & الحلوه نعناعه كايده الجماعه & Sweetie car, makes others turn green \\
\hline & الكل شمال & All are bad \\
\hline
\end{tabular}


Thus while authors in the statements about self or car used lexical items like 'King', الاصليه ('cutie'), (the original'), الدلوعة ('the pampered girl'), الحلوه ('sweetie'), الدبور('the fearsome man'), drawing a very positive image of themselves as steadfast, faithful, respectful, right etc., they draw a very negative image of "the other" who is unfaithful, nosey, incompetent (driver), spendthrift, disgraceful, dishonest etc.

\subsubsection{Social and Philosophical Expressions}

There were (87) vehicle graffiti in the social and philosophical discourse domain. For the purpose of this study, we merged the two graffiti categories as we found them overlapping in the majority of cases. This social and philosophical domain has six sub-themes, four positive and two negative. The positive sub-themes are contentment (13), motivational expressions (7), love (17) and wisdom (30), with a total of (67) cases representing (77.01\%). On the other hand, the negative social and philosophical expressions are represented in complaints (14) cases and threats (6) cases with a total of (20) cases $(22.98 \%)$. This is illustrated in Table 7. below.

Table 7. Types of Social \& Philosophical Expressions

\begin{tabular}{|c|c|c|}
\hline Type & Example & Translation \\
\hline \multirow[t]{4}{*}{ Contentment } & كده رضا & This is satisfactory \\
\hline & مش طمعان في لعبه زهر & I don't long for a stroke of luck \\
\hline & علمت أن رزقي لن يأخذه غيري فاطمأن & $\begin{array}{l}\text { I knew that my sustenance would not be taken by any } \\
\text { other person. So, my heart has rest assured. }\end{array}$ \\
\hline & القناعه كنز لا يفني & Contentment is a treasure hard to find \\
\hline \multirow{3}{*}{$\begin{array}{l}\text { Motivational } \\
\text { Expressions }\end{array}$} & مربوحه إن شاء الله & (My car is) profitable, if God wills \\
\hline & بنات أيه يا عّم أكل العيش أهم & $\begin{array}{l}\text { What do you say? Girls? Breadwinning is more } \\
\text { important. }\end{array}$ \\
\hline & إصبر تتول & Be patient and you will get (what you want) \\
\hline \multirow[t]{3}{*}{ Love } & لو مش نصيبي هيفضل حبيبي & If she is not my lot, she'll remain my love \\
\hline & 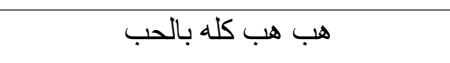 & It all comes when you fall in love \\
\hline & 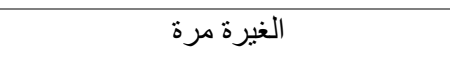 & Jealousy is bitter \\
\hline \multirow[t]{5}{*}{ Wisdom } & احتر ام الكبير واجب & Respect of the older people is a must \\
\hline & امتلك ما شئت سترحل كما جئت & $\begin{array}{c}\text { Possess what you want, you will (eventually) leave as } \\
\text { you (first) came }\end{array}$ \\
\hline & مش بالساهل تلقي اللي يستاهل & It's not easy to find someone who is worthy \\
\hline & نصييك هيصياك & Your destiny is inevitable \\
\hline & الانيا رخيصه على الغالي و غاليه على الرخيص & Life is cheap for the noble and dear for the mean \\
\hline
\end{tabular}

\begin{tabular}{|c|c|c|}
\hline \multirow[t]{2}{*}{ Complaints } & يتوب علينا ربنا & We repent to our Lord \\
\hline & رميت همومى في البحر طلع السمك يلطم & $\begin{array}{l}\text { I threw my cares into the sea, the fish leapt out of } \\
\text { water, wailing }\end{array}$ \\
\hline Threats & هتحكها هاجييك تحتها & You scratch it (i.e. the car) and I'll put you under it \\
\hline
\end{tabular}

\subsubsection{Political Expressions}

In a society that witnessed two revolutions over the past five years; namely, January 2011 and June 2013, it was expected to find political graffiti on vehicles as it was the case in wall graffiti in Egypt in 2011 and 2013 (See Gröndahl, 2012; Lennon, 2014). The data, however, reveal considerably few graffiti phrases that can be classified under this discourse theme ( 7 cases only). Four of such occurrences express patriotism and three carry a criticism to the government. 
Table 8. Types of Political Expressions

\begin{tabular}{|c|c|c|}
\hline Type & Example & Translation \\
\hline \multirow{2}{*}{$\begin{array}{l}\text { Patriotic } \\
\text { Expressions }\end{array}$} & بحبك يا بلادى & We love you, our country \\
\hline & 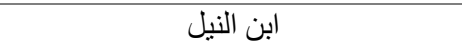 & Son of the Nile \\
\hline \multirow[t]{3}{*}{ Political Criticism } & يا حكومه سيبوني أعيش & O, government, let me live! \\
\hline & من جد وجد ومن تخرج قعد & $\begin{array}{c}\text { Whoever works hard, will reap the fruits, and whoever } \\
\text { graduates will remain jobless }\end{array}$ \\
\hline & لو سألونى عن العدل في بلاد المسلمين قل & $\begin{array}{l}\text { If they ask me about justice in the Muslim countries, say, } \\
\text { Omar (i.e. the Muslim Caliph known for justice) died. }\end{array}$ \\
\hline
\end{tabular}

Figure 4 below shows the map of discourse domains of Egyptian vehicle graffiti as illustrated in this study.

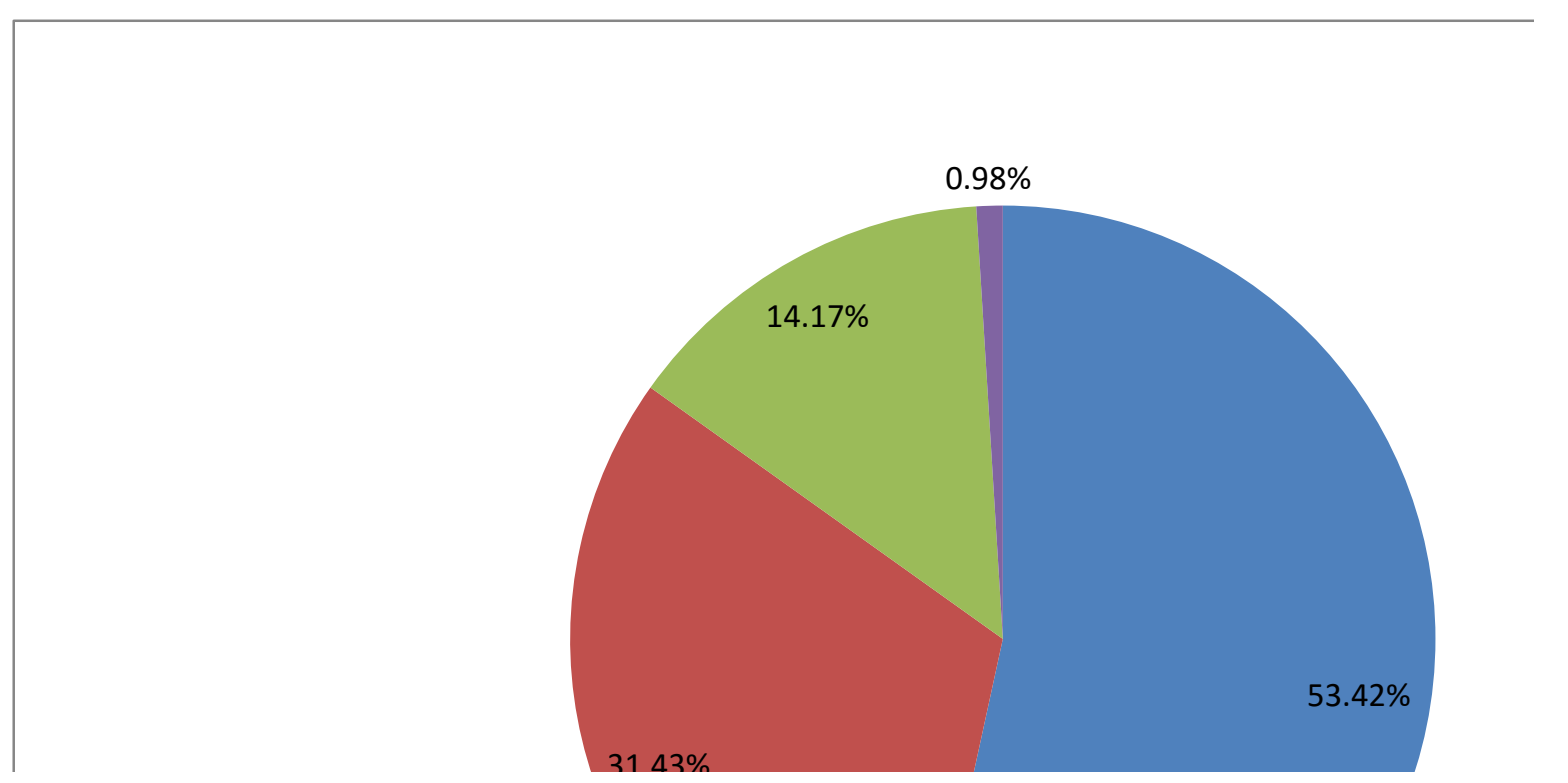

Figure 4. Map of vehicle graffiti discourse domains

\subsection{Language and language variation}

Vehicle graffiti authors used both Arabic and English for the graffiti. It is worth noting that as the source of data was mainly trucks and buses, the authors are expected to have a limited scope of education with modest knowledge of the English language. This was reflected in the very few occurrences of English language graffiti (20 cases only out of 614). Up to 15 of such instances are Arabic names written using English orthography and only (5) English statements. As for Arabic graffiti, the analysis showed 594 cases: Classical Arabic 290, Standard Arabic (75) and Colloquial Arabic (229), as shown in Figure 5 below.

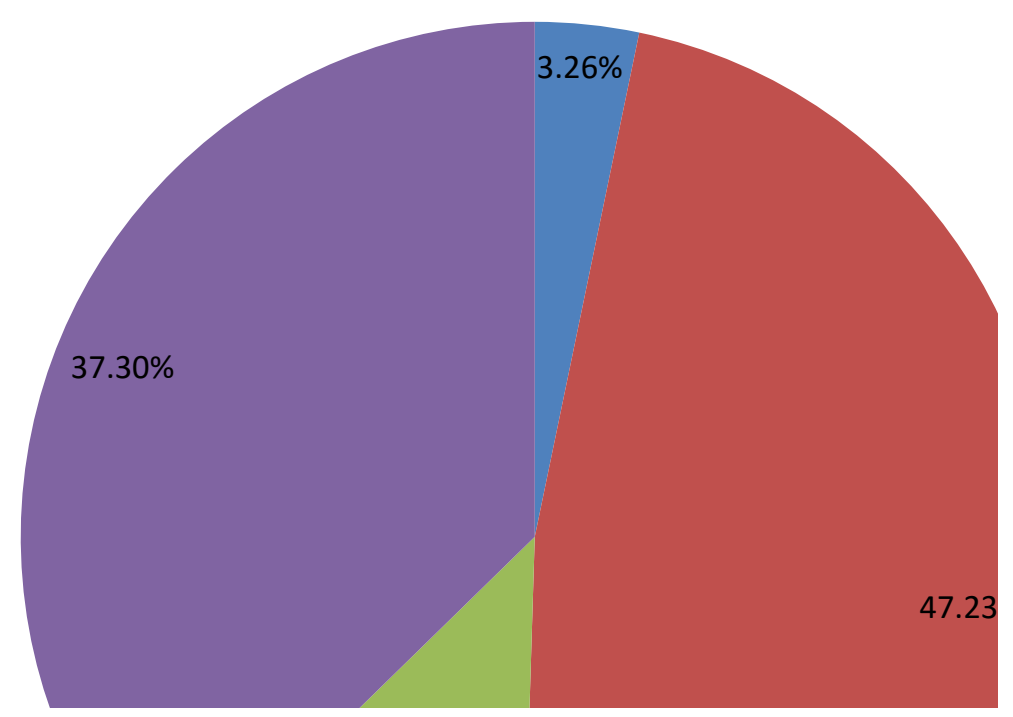

Figure 5. Language map of vehicle graffitip 


\section{Conclusion}

Whether viewed as egalitarian or authoritarian in nature, graffiti in general and vehicle graffiti in particular is a means of communication that give voice to the marginalized groups of society. As this study has shown, vehicle graffiti are not merely a reflection of individuals' thoughts and feelings, but are in themselves a social practice as well as a product of the practices of various institutions. This study has attempted to investigate vehicle graffiti in the streets of Egypt from a linguistic approach, adopting Fairclough's (1995) post-structuralist model of analysis. Through running a quantitative and qualitative analysis of (614) vehicle graffiti, the study showed that with regard to thematic classification, the majority of vehicle graffiti lie in the religious discourse domain. The sweeping majority of Islamic expressions and rare occurrences of Christian expressions show how such discourse genre reflects social and religious power relations in the Egyptian society.

The majority of religious expressions fell in the category of 'reaffirmation of faith' (53.66\%). Such reaffirmations were largely made through citations of Quranic verses with no occurrence of biblical citations. Graffiti authors also reaffirmed their faith using citations of Islamic/Christian sayings; God's Names as well as the name of Prophet Muhammad, Jesus and some Christian saints. The analysis also showed that Quranic citations constitute a significant portion of religious expressions (36.89\%) against (63.11\%) for the rest of religious expressions. The study also revealed a strong fear of envy that was reflected in the data $(29.27 \%)$ along with the appeal to God for protection against this supernatural power. In addition, the institutional preaching role of the mosque and Islamic community is apparent in the data under investigation with $(9.76 \%)$ of religious data taking the form of a one-sided dialogue in which the author preaches the society about various religious instructions. Personal invocations had the smallest number of occurrences in religious expression graffiti, scoring $(7.31 \%)$.

It is also shown from the analysis that in the identity expression graffiti, expressions of the self far outnumber those dealing with 'the other'. Two sharply contradicting images were drawn: a very positive self-image and a very negative image of 'the other'. The humorous and optimistic nature of Egyptians (Nayef \& El-Nashar, 2014) is also apparent in the data as the majority of the (87) social and philosophical graffiti are positive expressions (77.01\%) against (22.98\%) negative statements. Yet, if political graffiti were popular in Egypt after the two revolutions in 2011 and 2013, vehicle graffiti collected by the authors in $2015-2016$ showed a scanty $(0.98 \%)$ belonging to this discourse domain - a point that is worth studying per se in future study.

As far as language and language variations are concerned, the data revealed that vehicle graffiti authors who are mainly truck and bus drivers with a modest level of education used the classical and standard variations of Arabic more than they did the colloquial variation. This can be explained by the heavy dependence on Quranic and religious citations, which typify classical and standard Arabic respectively.

The study shows that vehicle graffiti should not be regarded only as a platform of communication for the underprivileged social and political groups. They are proved to be an ongoing discourse that is the product of various institutions that constantly influences, and is influenced by, them. In either case, vehicle graffiti will always stand out as 'the chants of the silent' (Eweis, 1971/2000).

\section{References}

Adams, K. L., \& Winter, A. (1997). Gang graffiti as a discourse genre. Journal of sociolinguistics, 1(3), $337-360$.

Ali, A. Y. (1975). The Glorious Quran: Translation and commentary. Eduright4all.

Basthomi, Y. (2009). Truck graffiti: The rhetoric of emulation. Dialogue Analysis XI, 217.

Best, C. (2003). Reading graffiti in the Caribbean context. Journal of Popular Culture, 828-852.

Bloch, L. R. (2000). Mobile discourse: Political bumper stickers as a communication event in Israel. Journal of Communication, 50(2), 48-76.

Brown, G. and Yule, G. (1983). Discourse Analysis. Cambridge: Cambridge University Press.

Bunting, A. M. (2012). A sociological study of graffiti in Seville, Spain. Journal of Student Research, 1(2), 51-54.

Cameron, D. (1985). Feminism and linguistic theory. Basingstoke: Palgrave.

Case, C. E. (1992). Bumper stickers and car signs ideology and identity. The Journal of Popular Culture, 26(3), 107119.

Chiluwa, I. (2008). Religious vehicle stickers in Nigeria: A discourse of identity, faith and social vision. Discourse \& Communication, 2(4), 371-387.

Divsalar, F., \& Nemati, A. (2012). Social pathology of trust in car written manuscripts. Mediterranean Journal of Social Sciences, 3 (3) 363-462.

Emmison, M., \& Smith, P. (2000). Researching the visual: Images, objects, contexts and interactions in social and cultural inquiry. London: Sage Publications.

Eweis, S. (1971/2000) Hutaaf 1-samiteen: THahirat 1-kitabah ?al hayakil 1-markabaat fi 1-mugtama? L-misri 1mu?aasir. [The Chants of the Silent: The Phenomenon of graffiti on Vehicles in the contemporary Egyptian society]: Maktabat 1-?srah 
Fairclough, N. (1989). Language and power. London: Longman

Fairclough, N. (1992). Discourse and social change. Cambridge: Polity Press.

Fairclough, N. (1995). Media discourse. London: Edward Arnold.

Farnia, M. \& Tohidian, I. (2013). A thematic analysis of truck graffiti in Iranian context. Paper presented at the first national conference on research in teaching English, translation and linguistics (RTELT), 2-3 March, Islamic Azad university of Khorasgan, Iran.

Farnia, M. (2014). A thematic analysis of graffiti on the university classroom walls: A case of Iran. International Journal of Applied Linguistics and English Literature, 3(3), 48-57.

Ferguson, C. (1959). The Arabic koine. Language, 35(4), 616-630.

Foucault, M. (1972). The Archaeology of knowledge. London: Tavistock.

Foucault, M. (1981). The order of discourse. In R. Young (ed.) Untying the text: A poststructuralist reader, pp. 48-78. London: Routledge \& Kegan Paul

Gadsby, J. M. (1995). Looking at the writing on the wall: A critical review and taxonomy of graffiti texts. Unpublished MA thesis. Boston: USA.

Grider, S. A. (1975). Con safos: Mexican-Americans, names and graffiti. The Journal of American Folklore, 88(348), 132-142.

Gröndahl, M. (2012). Revolution graffiti: Street art of the new Egypt. American University in Cairo Press.

Gross, D. D., Walkosz, B., \& Gross, T. D. (1997). Language boundaries and discourse stability: 'Tagging' as a form of graffiti spanning international borders. et Cetera, 54(3), 275.

Hanauer, D. I. (2004). Silence, voice and erasure: Psychological embodiment in graffiti at the site of Prime Minister Rabin's assassination. The Arts in Psychotherapy, 31(1), 29-35.

Hendrickx, S., Darnell, J. C., \& Gatto, M. C. (2012). The earliest representations of royal power in Egypt: The rock drawings of Nag el-Hamdulab (Aswan). Antiquity, 86(334), 1068.

House, S. (2007). "Too pretty to do math": The effect of negative, positive, and neutral bumper stickers on math performance in women. Unpublished M.A. dissertation, Chicago University.

Hunt, M. B. (1996). The sociolinguistics of tagging and Chicano gang graffiti. Unpulbished Ph.D., University of Southern California.

Jankowska, K. (1999). Próba klasyfikacji napisów graffiti. Literatura Ludowa, 3, 17-26.

Kalerante, E., \& Mormori, P. (2005). Graffiti as a form of social and cultural conflict. International Journal of the Humanities, 3(4).

Lennon, J. (2014). Assembling a revolution: Graffiti, Cairo and the Arab spring. Cultural studies review, 20(1), 237.

McGlynn, P. D. (1972). Graffiti \& slogans: Flushing the Id. The Journal of Popular Culture, 6(2), 351-356.

Mirzaalikhani, S. (2011). Iranian graffiti during political transformation: A semiotic analysis of graffiti before and after revolution. Ph.D. dissertation, Eastern Mediterranean University (EMU).

Moonwomon, B. (1995). The writing on the wall: A border case of race and gender. In K. Hall \& M. Bucholtz (Eds.), Gender articulated: Language and the socially constructed self, pp. 447-468. New York/London: Routledge

Mwangi, F. G. (2012). Graffiti writing and its likely influence on English language learning in selected secondary schools in the larger Laikipia East District, Laikipia County, Ph.D. dissertation, Kenyatta University.

Nayef, H., \& El-Nashar, M. (2014). Dissecting the poisoned honey: Sexist Humor in Egypt: A linguistic analysis of sexism in Colloquial Cairene Arabic jokes. Anàlisi, (50), 131-146.

Nwoye, O. G. (1993). Social issues on walls: Graffiti in university lavatories. Discourse \& Society, 4(4), 419-442.

Obeng, S. G. (2000a). Doing politics on walls and doors: A sociolinguistic analysis of graffiti in Legon (Ghana). Multilingua, 19(4), 337-365.

Obeng, S. G. (2000b). Speaking the unspeakable: Discursive strategies to express language attitudes in Legon (Ghana) graffiti. Research on Language and Social Interaction, 33(3), 291-319.

Peiris, D., \& Jayantha, K. (2015) A Case study on emotion types of graffiti writers in jogging paths, Sri Lanka. International Journal of Humanities and Social Science 20(7):2279-0845

Rains, S. A., Tumlin, G. R., \& Knapp, M. L. (2009). Electronic bumper stickers: the content and interpersonal functions of messages attached to e-mail signatures. Discourse Studies, 11(1), 105-120.

Reisner, R. (1971). Graffiti: Two thousand years of wall writing. Cowles Book Company.

Russell, E. (2008). Writing on the wall: The form, function and meaning of tagging. Journal of Occupational Science, 15(2), 87-97.

Salamon, H. (2005). Ha' am in the turbulent discursive sphere of Israeli bumper stickers. Hebrew Studies, 197-234. 
Sheivandi, L., Taghinezhad, A., Alishavandi, A., \& Ranjbar, S. (2015). Exploring linguistic aspects in Iranians' graffiti. Journal of Applied Linguistics and Language Research, 2(5), 62-73.

Szpila, G. (2003). Co mur, to mądrość narodu-przysłowie w graffiti po polsku. [Every wall has its folk wisdomProverbs in Polish graffiti.]. Literatura Ludowa, 3, 35-42.

Szpila, G. (2012). Regulating the reality? Proverbs in Polish graffiti. Estonia and Poland. Creativity and tradition in cultural communication, 1, 269-284.

Van Dijk, T. (1985) Handbook of Discourse Analysis. 4 vols. London: Academic Press.

Van Dijk, T. A. (2001). Critical discourse analysis. The handbook of discourse analysis, 349-371.

van Dijk, T.A. (2006). Racism and the press in Spain. In J. Blas, M. Casanova, M. Velando, \& J. Vellón, (Eds.), Discurso y Sociedad II. Nuevas contribuciones al estudio de la lengua en un contexto social, pp. 59-99. Castelló de la Plana: Universitat Jaume I.

Yieke, F. (2003). Graffiti: Vandalism or expression of academic freedom and intellectualism at universities in Kenya. In Conference on Canonical Works and Continuing Innovation in African Arts and Humanities at the University of Ghana in Legon, Accra, 17th-19th September.

Younes, M. (2006). Integrating the colloquial with Fusha in the Arabic as a Foreign Language Classroom. In K. Wahba, Z. Taha, \& L. England, Handbook for Arabic Language Teaching Professionals, pp. 157-166. Mahwah, NJ: Lawrence Erlbaum. 